\title{
Formation of ecological education of the population
}

\author{
Valery Litvishko ${ }^{1^{*}}$, Aigul Akhmetova ${ }^{2}$, Gaukhar Kodasheva ${ }^{3}$, Aigerim Zhussupova ${ }^{3}$, Rilla \\ Malikova $^{4}$, Aigerim Kuralova ${ }^{4}$ \\ ${ }^{1}$ Plekhanov Russian University of Economics, 36, Stremyanny lane, 117997, Moscow, Russian \\ Federation \\ ${ }^{2}$ Korkyt Ata Kyzylorda State University, 29A Aiteke bie str, 120014 Kyzylorda, Kazakhstan \\ ${ }^{3}$ L.N. Gumilyov Eurasian National University, Nur-sultan, Kazakhstan \\ ${ }^{4}$ al-Farabi Kazakh National University, 71 al-Farabi Ave., 050040 Almaty, Kazakhstan
}

\begin{abstract}
This article analyzes the concepts and role of environmental education of the population, and also discusses the problems of forming an ecological outlook among young people in the Republic of Kazakhstan. Solving global issues, including environmental protection, fighting the consequences of the environmental crisis, is comprehensive, including in the field of education. The solution to the vital environmental issues and problems faced by the world community is largely correlated with the prosperity of environmental education and the upbringing of the future generation. In this regard, the pedagogical and social aspects of environmental education and the education of young people is the main issue in the period of modernization in Kazakhstan. The problem of environmental education of young people should be regarded as a sovereign and self-valuable area of the educational development of the people's personality. The characteristic features include understanding of the goals, objectives and detectors of the effectiveness of education, the orientation of educational interaction in solving global and local environmental issues, reinforcement of environmental education and practical activities of public non-governmental organizations.
\end{abstract}

\section{Introduction}

The modern world is a highly developed technological system. A huge number of enterprises operate in the world, widely using the latest technologies. Today, people are very concerned about technological and industrial progress, few people think about the environmental component of the issue. But our nature does not have an unlimited reserve of safety.

\footnotetext{
*Corresponding author: ol-1@ mail.ru
} 
Under prevailing objective and subjective factors of a socioeconomic and political nature, modern Kazakhstan has become a country of "continuous environmental risk", an unfavorable environmental situation has developed over almost the entire territory of the republic. In order to improve the environmental crisis, an important role is played by the formation of an ecological culture among the younger generation. The current environmental situation sharply raised the question of revising socio-cultural attitudes, values, goals, and the degree of rationality of our attitude to nature. The way out of the crisis largely depends on how high the level of environmental consciousness of people will be. This means that in solving one of the most difficult tasks of our time, a special role belongs to pedagogical science and practice. It is no accident that environmental education has become one of the priority areas for reforming the national secondary and higher education.

To eliminate environmental problems, the country needs competent, educated specialists. In this regard, in the universities of Kazakhstan, bachelors, specialists, and masters of ecology are being trained, the environmental component of biological, chemical and geographical education has been significantly strengthened, a specialty "teacher ecologist" has appeared in some faculties of pedagogical universities. But a contradiction inevitably arises: problems are created by everyone together, and a small group of specially trained people should solve them. At present, the situation in the ecology of our country is such that in order to change something, it is necessary to accumulate all possible resources. In this regard, it is fundamentally important to educate a new generation with a developed ecological worldview, which involves understanding the inextricable links of human and nature, their attitude to nature as an element of culture, a sense of responsibility for whatever is accepted by human and society.

Figure 1. Ways to eliminate ecological crisis.

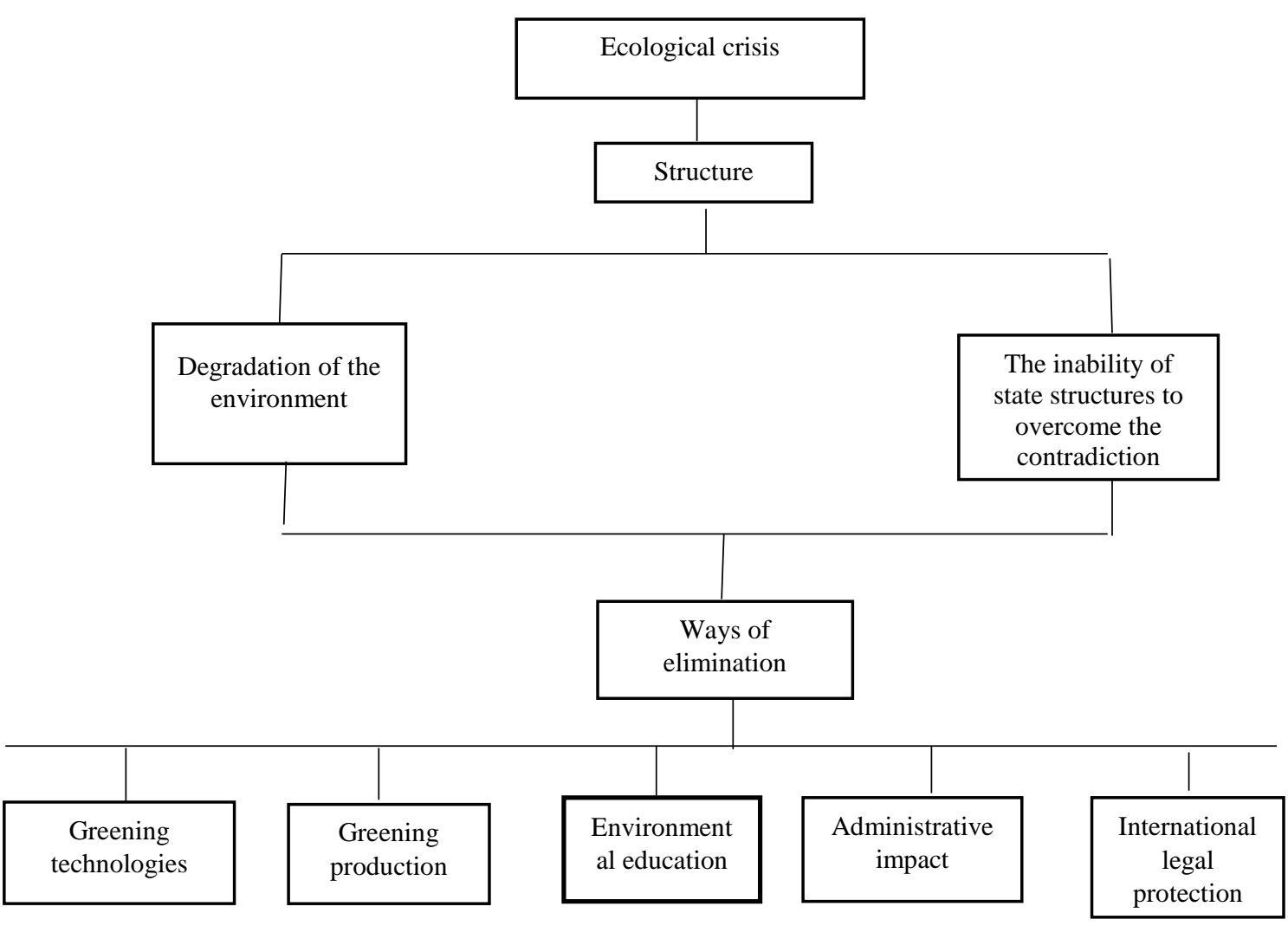




\section{Literature review}

Conducting relevant, high-quality scientific research and sharing the findings with decisionmakers is not enough to solve complex environmental and conservation issues [1-3]. Rather, we need synergistic spaces where research findings are interpreted and applied in on-the-ground contexts in ways that acknowledge and meld with social, political, and economic milieus [3].

Environmental education is a conservation strategy that creates such synergistic spaces, enabling opportunities for scientists, researchers, community members, and other stakeholders to converge. Environmental education actualizes local knowledge, experience, values, and practices, often in place-based entourages; in this way, it encourages numerous groups, including those that may be marginalized, to interface productively with research [3]. By definition, environmental education implicates approaches, tools, and programs that develop and support environmentally related attitudes, values, awareness, knowledge, and skills that prepare people to take informed action on behalf of the environment [4]. It focuses on outcomes at various scales, including at the individual level (e.g., an individual's environmental attitudes or behavior), societal level (e.g., community capacity-building), and ecosystem level (e.g., number of an endangered species). Based on a growing body of research foregrounding behavioral complexity, environmental education has moved away from suggesting a linear path from environmental attitudes to knowledge to action, now emphasizing a dynamic, complex ecosystem of relationships that influence behavior rather than earlier ideas derived from an information-deficit perspective [5].

Education can lead to changes in green behavior and the engagement of daily life environmental choices. Environmental knowledge is important in producing ecological behaviors because an individual must know what type of action to take [6]. The role of the teachers is fundamental in shaping the future of the students and this could be done at the primary level of school life only. Hence, the elements of leadership and their influence on the teaching behavior is high [7]. Environmental education can serve as a critical tool in countering environmental problems as it strives toward the goal of environmental protection and conservation [8,9]. Environmental education sights to impact not only an individual's internal understandings of the world, but ultimately to intrinsically induce people to perform corresponding behaviors. Indeed, education is regarded as an irreplaceable requirement if we want to put forward sustainable development successfully.

The environmental education is defined as a way of rethinking our relations with the biosphere as well as an instrument of social transformation towards a sustainable development [10]. Thereby, environmental education may play a critical role facing two inevitable challenges. First, the ecological challenge, which involves helping to train not only young people and children, but also managers, planners to guide their values and behaviors towards a balanced relationship with nature. Then, the social challenge which incite us to radically transform the structures of management and allocation of the resources of the earth [11]. In turn, a better comprehension about how education impact on green behavior become an essential issue for policy-makers.

Many papers find that education is positively correlated with environmental behavior in a range of scopes. For instance, numerous studies find that individuals with higher education are more likely to recycle [12-16]. Other research finds that education is correlated with food choices that affect the environment. For example, Blend and Van Ravenswaay [17] find that higher levels of education increase the probability that a consumer would purchase eco-labeled apples. Several others find that education is 
associated with a higher probability of purchasing organics [18-20]. Some studies have found that higher education levels are correlated with water saving behaviors [21, 22]. Furthermore, there is evidence that education is associated with more pro-environmental attitudes. For example, Rowlands [23] find evidence that more educated individuals are willing to contribute more for green electricity. Xiao [24] find that more highly educated Chinese citizens report higher levels of environmental concern and De Silva and Pownall [25] find that college educated individuals are more likely to sacrifice financial well-being to improve environmental quality.

While the education about the environment becomes more important in the changing world, as its natural consequence, environmental education gets higher attention in the educational curriculum of the countries [26]. However, it is impossible to claim that the point reached in education is sufficient for the young generation to understand the importance of environmental conservation. At last, we know that in the origin of the environmental problems, there are social, economic and cultural factors and they will not be able to be solved by using technology solely. So, the basic principle for the environmental education is to keep on to educate population about their values, attitudes and behaviors which they hold towards the environment.

\section{Methodology}

The information used in the methodology of this article was taken from the statistical results of the Environmental Performance Review (EPR). EPRs for countries with transition economies were initiated by the Ministers of the Environment at the Second Environment for Europe Conference in Lucerne, Switzerland, in 1993.

The preparation of the second environmental performance review of Kazakhstan began in April 2007 with a preparatory mission, during which the final structure of the report was discussed and approved. The review mission took place from September 10 to 19, 2007. The group of international experts included experts from Italy, Finland, France and Sweden and from the secretariats of the United Nations Economic Commission for Europe (UNECE) and the Organization for Economic Co-operation and Development (OECD) [27].

The reviews, performed under the auspices of the UNECE in the case of countries in transition, are conducted via a peer review panel of outside experts, with the participation of the relevant domestic government officials, experts and public stakeholders. The World Health Organization (WHO) provides expertise in environmental health issues and developed a chapter on Environmental Health within the EPRs.

The Environmental Code and the Concept of the Transition of the Republic of Kazakhstan to Sustainable Development (CTSD) contain provisions on environmental education and training, as well as education for sustainable development (ESD). The plan of the Ministry of the Environment for the Implementation of the CTSD contains specific actions to promote environmental education and ESD. The Ministry of the Environment and the Ministry of Education and Science jointly approved the Concept of Environmental Education (respectively, Orders No. 229-p of September 24, 2003 and No. 697 of September 25, 2003). Since this document was not supplemented by a specific action plan after its approval, it is very difficult to assess its impact.

The Ministry of Education and Science does not have a pivotal point responsible for environmental education and ESD. The action plan for the implementation of the state education development program for 2005-2010 years does not include environmental 
education and ESD measures. There is not enough interaction between the ministries and the main stakeholders in the process.

Kazakhstan takes part in international cooperation on ESD - a regional initiative of the UNECE, which resulted in the development and approval of the ESD Strategy in 2005. To date, Kazakhstan has not taken concrete steps to implement this strategy at the national level.

\section{Preschool and school education}

In 2001, environmental issues were included in the compulsory requirements of preschool education. Every year in Kazakhstan, twenty-four environmental classes are held for three-year-olds and forty-eight classes for children aged four to six years. Appropriate environmental programs have been developed; Environmental issues have been added to preschool teacher programs. Kazakhstan promotes environmental education among students by introducing specific environmental issues into school courses in natural sciences, including biology, geography, chemistry and physics. There is no evidence that these issues are included in social studies courses. Ecology itself is taught optionally. The lack of a conceptual approach to environmental education in schools gives rise to doubt that most school graduates have a holistic understanding of environmental issues. In-depth study of environmental disciplines is offered in only a few schools.

\section{Professional and higher education}

The environmental course is not included in the curriculum of any institution of secondary technical education in Kazakhstan. There are no vocational and technical institutions training specialists in the field of environmental protection in the Republic. Ecology has become a compulsory subject of study in all higher education institutions. However, unlike other compulsory subjects, it is not required to take a test or an environmental exam at the end of the semester, which for obvious reasons requires less effort from students. The Ministry of the Environment would like to change the subject of the course to a course on sustainable development, at the end of which an exam would be envisaged.

There are a number of specialized environmental training programs, including the topics "Ecology", "Life Safety and the Environment" and "Water Resources and Water Use". Such topics are taught only in about thirty universities of the Republic. There are still no curricula in such important subjects as environmental management, environmental law and environmental control. Due to the lack of training in the above disciplines, there is a shortage of specialists in the public and private sectors that Kazakhstan needs as a state with rapidly developing environmentally harmful industries.

\section{Training}

The Ministry of the Environment information and analytical center is a leading organization for retraining and advanced training of specialists in the field of environmental protection and nature management. Since 2005, the Center for Retraining and Advanced Training in the Field of Environmental Protection and Nature Management has been operating under his leadership. From 2005 to 2007 the center trained about 900 specialists who completed five-day courses in state environmental inspection, environmental permitting system, audit, insurance and environmental management. Persons undergoing training are mainly employees of the Ministry of the Environment. In addition, the Kazakhstan Research Institute of Ecology and Climate provides courses for enterprises on specialized topics such as the handling of ozone-depleting substances. The leadership of the Academy of Public Administration, the main public institution for the retraining of civil servants, has included environmental subjects in its curriculum.

No government body is directly responsible for informal and non-formal adult education. These types of education are provided by non-governmental organizations and 
Regional Environmental Center for Central Asia. Their projects, in many respects, depend on contributions from external investors, and therefore have a short-term nature [29].

Table 1. Investments aimed at protecting the environment by type of economic activity of the investor [28].

\begin{tabular}{|c|c|c|c|c|}
\hline & 2015 & 2016 & 2017 & 2018 \\
\hline Total & 82883241 & 43936904 & 86961995 & 111161429 \\
\hline \multicolumn{5}{|c|}{ thousand tenge } \\
\hline Agriculture, forestry and fisheries & 217547 & 43355 & 980 & 50725 \\
\hline Manufacturing & 62641222 & 31641745 & 58727741 & 94337719 \\
\hline Construction & 20291 & - & 15401018 & 1706393 \\
\hline Wholesale and retail trade & 1379 & - & 1229 & 6777140 \\
\hline Information and Communication & 43720 & 1977 & 2269 & - \\
\hline Financial and insurance activities & 12162 & - & - & - \\
\hline Real estate operations & 512 & 4368 & 14449 & - \\
\hline $\begin{array}{l}\text { Professional, scientific and technical } \\
\text { activities }\end{array}$ & 8399903 & 1884958 & 437378 & 2290730 \\
\hline Administrative and support activities & 1725 & - & - & 17 \\
\hline Public Administration and Defense & 10321192 & 10356503 & 11576674 & 5985607 \\
\hline Education & 774 & - & 221 & 12294 \\
\hline Health and social services & - & 2302 & - & - \\
\hline Other types of services & 1162317 & 1696 & 800000 & 804 \\
\hline
\end{tabular}

In addition, according to governmental statistics, the share of allocated investment is extremely low for education from investments aimed at protecting the environment by type of economic activity of the investor. Before 2015 year most of the years investments were even not allocated for environmental education.

The SWOT-analysis gives better insight on environmental education and its impact to the whole local environment, and shows relevant problems and opportunities of ecological education in Kazakhstan.

Table 2. The SWOT-analysis of ecological education in the Republic of Kazakhstan.

\begin{tabular}{|c|c|}
\hline \begin{tabular}{|l} 
Strengths \\
\end{tabular} & $\begin{array}{c}\text { Weaknesses } \\
\end{array}$ \\
\hline $\begin{array}{l}\text { - The legislation of the state contains the } \\
\text { "Environmental Code of the Republic of } \\
\text { Kazakhstan", in the 25th chapter of which } \\
\text { there is a section on Environmental } \\
\text { Education and Enlightenment, advanced } \\
\text { training of specialists; } \\
\text { - Environmental education is available at all } \\
\text { levels of education, from elementary } \\
\text { schools to training environmental }\end{array}$ & $\begin{array}{l}\text { - The Ministry of Education and Science } \\
\text { does not have a primary point responsible } \\
\text { for environmental education and education } \\
\text { for sustainable development; } \\
\text { - There is not enough interaction between the } \\
\text { ministries and the main stakeholders in the } \\
\text { process; } \\
\text { - Kazakhstan has not taken concrete steps to } \\
\text { implement ESD Strategy at the national }\end{array}$ \\
\hline
\end{tabular}




\begin{tabular}{|c|c|}
\hline $\begin{array}{l}\text { professionals; } \\
\text {-Ecological education is supported } \\
\text { financially by governmental and non- } \\
\text { governmental organizations; } \\
\text { - Kazakhstan takes part in international } \\
\text { cooperation on education for sustainable } \\
\text { development. }\end{array}$ & $\begin{array}{l}\text { level; } \\
\text { - Lack of a conceptual approach to } \\
\text { environmental education in schools; } \\
\text { - In-depth study of environmental } \\
\text { disciplines is offered in only a few schools; } \\
\text { - The environmental course is not included } \\
\text { in the curriculum of any institution of } \\
\text { secondary technical education in } \\
\text { Kazakhstan; } \\
\text {-There is a shortage of specialists in the } \\
\text { public and private sectors. }\end{array}$ \\
\hline Opportunities & \\
\hline $\begin{array}{l}\text {-Conversion of traditional teaching methods } \\
\text { into modern, game-like techniques in } \\
\text { schools; } \\
\text {-Attracting more investment to ecological } \\
\text { education; } \\
\text {-Adoption of nature-based ecological } \\
\text { education: close interaction of students with } \\
\text { nature during the lessons; } \\
\text {-Using theory of nudging to direct } \\
\text { population to the right choice. }\end{array}$ & $\begin{array}{l}\text {-Large amount of expenditures and time; } \\
\text {-Lack of resources and diversifications; } \\
\text {-Ignorance of ecological issues by } \\
\text { population; } \\
\text {-Lack of teacher preparation and } \\
\text { qualification; } \\
\text {-Lack of a concrete and formalized } \\
\text { approach toward environmental population } \\
\text { education. }\end{array}$ \\
\hline
\end{tabular}

\section{Conclusion and suggestions}

In issues of environmental protection, there are quite a few "advanced" laws, but these laws simply do not work or, at least, are not fully implemented. The vast majority of the population and business are outside the ecological information space and does not have any environmental education. In a word, there is a lack of information resources, courses accessible to the general public, but most importantly, there is no proper environmental education system.

The role of school education in the formation of environmental awareness in Kazakhstan is still very low, albeit the school curriculum includes environmental education in the form of classroom hours on environmental education for students in grades 5-11, as well as electives. The format of the standard presentation of environmental information is very outdated and not interesting for students. Although in European countries such information is presented very efficiently, since it is based on interactive, game and modeling exercises $[29,30]$.

The lack of a conceptual approach to environmental education in schools raises doubts that most graduates will have a holistic view of environmental issues. Programs of occupational schools do not contain a course in ecology. University programs also do not include important subjects such as environmental management, environmental law and environmental control. Due to the lack of training in the above disciplines, there is a shortage of specialists in the public and private sectors that Kazakhstan needs as a state with rapidly developing environmentally harmful industries. A government body has not been defined that would have clear responsibility for informal environmental education for adults.

To improve the situation in environmental matters, in particular, to increase environmental awareness in society, one can resort to the nudge theory from behavioral economics established by Richard Thaler. According to this theory, people are far from 
rational in their choices; they are more often oriented toward momentary desires, without taking into account the long-term consequences. Therefore, it seems important to guide and suggest in making the right decision among many others. As a result, the theory of nudging implies a "push", i.e. indirect direction of people to the right choice, while leaving them the right to choose.

"Pushing people" to the right choice or positive motivation will be effective if the following principles are observed: "nudging" is simple and understandable for most people; the influence of social norms, or society as a whole, is taken into account; they are convenient and easy to implement; they clearly show that losses are undesirable, and acquisitions are important.

It is also recommended to the Ministry of Education and Science, in collaboration with the Ministry of the Environment and other ministries responsible for specific areas of training (for example, the Ministry of Health), to establish an interagency coordination mechanism for education for sustainable development (ESD). Such a mechanism should include the participation of specialists in pre-school, school, occupational and higher education, as well as informal education, and representatives of other interested parties, including NGOs and the media, which would facilitate the implementation at the national level of the UNECE strategy on ESD.

Overall, to achieve the constant environmental behavior of the young generation through environmental education, the following actions are necessary:

-Strengthening environmental awareness of the population;

-Expansion of environmental educational programs for the training and professional development of various population groups;

-Development and implementation of interactive methods of environmental education for employees of state and executive bodies (seminars, round tables, etc.);

-Development and implementation of the organizational framework for monitoring public environmental awareness;

-Creating a system of access to environmental information through modern information technology.

\section{References}

1. A.T. Knight, C.N. Cook, K.H. Redford, D.Biggs, C.Romero, A Ortega-Argueta, C.D. Norman, B Parsons, M. Reynolds, G. Eoyang, M.Keene (2019) https://doi.org/10.1007/s11625-019-00676-X.

2. M.C. Lemos, J.C. Arnott, N.M. Ardoin, K. Baja, A.T. Bednarek, A. Dewulf, C. (2018) https://doi.org/10.1038/s41893-018-0191-0.

3. A. H. Toomey, A.T. Knight, J.Barlow, Navigating the space between research and implementation in conservation, (10) 619-625, (2017) https://doi.org/10.1111/conl.12315.

4. M. C. Monroe, M. E. Krasny, Across the Spectrum:North American Association for Environmental Education, (Washington, DC. 2016)

5. T. Marcinkowski, A. Reid, Reviews of research on the attitude-behavior relationship and their implications for future environmental education research, (25) 459-471 (2019) https://doi.org/10.1080/13504622.2019.1634237.

6. S. Otto, P. Pensini,. Global Environmental Change, (47) 88-94. (2017)

7. Z. Sayabek, M. Ainur, T. Ulan, A. Gulvira, K. Aizhan, T. Zhanar, Role of leaders in developing expertise in teaching and their influence on teachers in Kazakhstan. Academy of Strategic Management Journal, (2018)

8. G. Potter, J. Environ, Environmental education for the 21st century: where do we go now? Educ, (41) 22-33 (2009) 
9. J. Palmer, Environmental Education in the 21st Century: Theory, Practice, Progress and Promise. Routledge, ( London 1998)

10. A. J. Colom, J. Sureda, Hacia una teoría del medio educativo (bases para una Pedagogía ambiental). Palma de Mallorca: Servicio de Publicaciones Universidad de Palma de Mallorca (1981)

11. M. Novo, Environmental education, a genuine education for sustainable development. Rev. Educ. 195-217 (2009)

12. S. J. Callan, J. M. Thomas, Analyzing demand for disposal and recycling services: a systems approach. East. J. Econ. 32 (2), 221-240 (2006)

13. V. G. Duggal, C. Saltzman, M. L. Williams, Recycling: an economic analysis. East. J. Econ. 17 (3), 351-358 (1991)

14. I. Ferrara, P. Missios, Recycling and waste diversion effectiveness: evidence from Canada. Environ. Resour. Econ. 30 (2), 221-238 (2005)

15. J. D. Reschovsky, S. E. Stone, Market incentives to encourage household waste recycling: paying for what you throw away. J. Policy Anal. Manage. 13 (1), 120-139 (1994)

16. V.K. Smith, Does education induce people to improve the environment? J. Policy Anal. Manage. 14 (4), 599 (1995)

17. J. R. Blend, van E.O. Ravenswaay, Measuring consumer demand for ecolabeled apples. Am. J. Agric. Econ. 81 (5), 1072-1077 (1999)

18. A. C. Bellows, B. Onyango, A. Diamond, W. K. Hallman, J. Agric, Understanding consumer interest in organics: production values vs. purchasing behavior. Food Ind. Organ. 6 (1) (2008)

19. S. Monier, D. Hassan, V. Nichele, M. Simioni, J. Agric, Organic food consumption patterns. Food Ind. Organ, 7 (2) (2009)

20. L. Zepeda, J. Li, J. Agric, Characteristics of organic food shoppers. Appl. Econ. 39 (01) (2007)

21. R. Berk, D. Schulman, M. McKeever, H. Freeman, Measuring the impact of water conservation campaigns in California. Clim. Chang. 24 (3), 233-248 (1993)

22. A. Gilg, S.Barr, Behavioural attitudes towards water saving? Evidence froma study of environmental actions. Ecol. Econ. 57 (3), 400-414 (2006)

23. I. H. Rowlands, D. Scott, P. Parker, Consumers and green electricity: profiling potential purchasers. Bus. Strateg. Environ. 12 (1), 36-48 (2003)

24. C. Xiao, R. E. Dunlap, D. Hong, Q .Sci, The nature and bases of environmental concern among Chinese citizens. 94 (3), 672-690 (2013)

25. Akhmetshin, E. M., Ibatullin, R. R., Gapsalamov, A. R., Vasilev, V. L., \& Bakhvalov, S. Y. (2019). International Journal of Educational Management, 33(2), 1-20. doi:10.1108/IJEM-02-2018-0082

26. B. Jensen, K. Schnackthe, The action competence approach in environmental education. Environmental Education Research, 3( 2),163-178 (1997)

27. Ziyadin, S., Shash, N., Kenzhebekova, D., Yessenova, G., \& Tlemissov, U. (2018). Data in brief, 18, 1127-1133. (10) DOI: 10.1016/j.dib.2018.03.137

28. Environmental indicators of monitoring and evaluation of the environment: Investments aimed at protecting the environment by type of economic activity of the investor.

https://stat.gov.kz/ecologic/indicator

29. Mutanov, G., Ziyadin, S. /E3S Web of Conferences, DOI: $10.1051 /$ e3sconf/201913504056 (2019)

30. Voropai, O., Pichyk, K., \& Chala, N. Economics \& Sociology, 12(4), 228-332. (2019). 